\title{
Collagen Cross-Linking
}

\section{ISOLATION OF CROSS-LINKED PEPTIDES FROM COLLAGEN OF CHICKEN BONE}

\author{
By DAVID R. EYRE* and MELVIN J. GLIMCHER $\dagger$ \\ Department of Orthopaedic Surgery, Harvard Medical School, \\ Children's Hospital Medical Center, Boston, Mass. 02115, U.S.A.
}

(Received 12 March 1973)

\begin{abstract}
Cross-linked peptides were isolated from chicken bone collagen that had been digested with $\mathrm{CNBr}$ or with bacterial collagenase. Analyses of ${ }^{3} \mathrm{H}$ radioactivity in disc electrophoretic profiles of the $\mathrm{CNBr}$ peptides from bone collagens that had been treated with $\mathrm{NaB}^{3} \mathrm{H}$ indicated that a major site of intermolecular cross-linking in chicken bone collagen is located between the carboxy-terminal region of an $\alpha 1$ chain and a small $\mathrm{CNBr}$ peptide, probably situated near the amino-terminus of an $\alpha 1$ or $\alpha 2$ chain in an adjacent collagen molecule. A small amount of this cross-linked $\mathrm{CNBr}$ peptide was isolated from a $\mathrm{CNBr}$ digest of chicken bone collagen by column chromatography. Amino acid analysis showed that the $\mathrm{CNBr}$ peptide, $\alpha 1 \mathrm{CB} 6 \mathrm{~B}$, the carboxy-terminal peptide of the $\alpha 1$ chain, was the major $\mathrm{CNBr}$ peptide in the preparation, and the reduced crosslinking components were identified as hydroxylysinohydroxynorleucine (HylOHNle), with a smaller amount of hydroxylysinonorleucine (HylNle). However, the composition and the low recovery of the cross-linking amino acids suggested that the preparation was a mixture of $\mathrm{CNBr}$ peptides $\alpha 1 \mathrm{CB} 6 \mathrm{~B}$ and $\alpha 1 \mathrm{CB} 6 \mathrm{~B}$ cross-linked to a small $\mathrm{CNBr}$ peptide whose identity could not be determined. A small cross-linked peptide was isolated from chicken bone collagen that had been reduced with $\mathrm{NaB}^{3} \mathrm{H}_{4}$ and digested with bacterial collagenase. This peptide was the major cross-linked peptide in the digest and contained a stoicheiometric amount of the reduced cross-linking compounds. A peptide which had the same amino acid composition, but contained the cross-linking compounds in their reducible forms, was isolated from a collagenase digest of chicken bone collagen that had not been treated with $\mathrm{NaBH}_{4}$. The absence of the reduced cross-links from this peptide indicates that, at least for the cross-linking site from which the peptide derives, natural reduction is not a significant pathway for biosynthesis of stable cross-links. However, most of the reducible cross-linking component in the peptide appeared to stabilize in the bone collagen by rearrangement from aldimine to ketoamine form.
\end{abstract}

Recent work on the nature of cross-links in collagen has emphasized the central role of the aldehydes derived from lysyl and hydroxylysyl residues, and their subsequent reaction with each other to form aldols, or with unmodified lysyl and hydroxylysyl residues to form aldimines (see Traub \& Piez, 1971; Gallop et al., 1972). Each collagenous tissue, such as skin, tendon, bone, cartilage etc., reveals a unique and characteristic profile of the reducible cross-linking compounds on analysis after reduction with $\mathrm{NaB}^{3} \mathrm{H}_{4}$ (Bailey et al., 1970a; Eyre \& Glimcher, 1972a). In soft-tissue collagens major components also involve histidine residues which apparently participate in the formation of more complex reduc-

* Present address: The Kennedy Institute of Rheumatology, Bute Gardens, London W.6, U.K.

† To whom requests for reprints should be addressed. ible cross-linking compounds (Tanzer et al., 1973), whereas in bone collagen these compounds are not major reducible components (Mechanic et al., 1971). The mineralized collagens of bone and dentine (Mechanic et al., 1971; Davis \& Bailey, 1971), the collagen of cartilage (Bailey, 1971), and also the collagens of several invertebrate tissues (Bailey, 1971; Eyre \& Glimcher, 1971), have the aldimine crosslink, dehydro-hydroxylysinohydroxynorleucine (dehydro-HylOHNle), as their major reducible crosslink, with a smaller amount of dehydro-hydroxylysinonorleucine (dehydro-HylNle). The concentration of these reducible compounds in collagen apparently falls as connective tissues age, suggesting that they are modified to other, more stable crosslinks (Bailey et al., 1970a; Bailey \& Shimokomaki, 1971). Evidence has been presented suggesting that the aldimine cross-links of bone and dentine collagens 
are stabilized by reduction in vivo to secondary amines (Mechanic et al., 1971). However, the major reducible cross-link of the mineralized collagens, dehydroHylOHNle, itself appears to be relatively stable, resisting heat- and acid-treatment (Davis \& Bailey, 1971; Bailey et al., 1970b).

Despite the relative abundance of information on the chemical structure of intermolecular cross-links in collagen, little is known about the relative contributions of these reducible compounds to the structural stability of collagen fibrils, nor is much information available on the precise locations of these bonds within the collagen molecules. It is, however, generally agreed that the two ends of the collagen molecule are important sites of the precursor aldehydes that participate in cross-link formation.

Much of our knowledge on the primary structure of collagen stems from analysis of the peptides released by digestion of the collagen chains with $\mathrm{CNBr}$. For example, in chicken bone the collagen molecule has the chain composition $(\alpha 1)_{2} \alpha 2$. The $\alpha 1$ chain gives ten $\mathrm{CNBr}$ peptides which were originally assigned numbers, such as $\alpha 1 \mathrm{CB} 1, \alpha 1 \mathrm{CB} 2$, etc., according to their order of elution during column chromatography, and are now known to have the sequence 0-1-2-5-5-8-3-7-6A-6B in the $\alpha 1$ chain (Piez et al., 1969). Similarly, the $\alpha 2$ chain has six $\mathrm{CNBr}$ peptides with the sequence 1-0-4-2-3-5 (Vuust et al., 1970).

The present paper describes the isolation and analysis of cross-linked peptides from chicken bone collagen after digestion with $\mathrm{CNBr}$ or with bacterial collagenase. The results indicate the location of a major cross-linking site in the collagen molecule and illustrate the high stability of the non-reduced, dehydro forms of the reducible cross-links of bone collagen.

\section{Materials and Methods}

\section{Preparation of bone collagen}

Shafts of metatarsal bones from 12-14-week-old chickens were cleaned, dried, powdered and demineralized in 0.2M-EDTA, pH7.9, as described (Eyre \& Glimcher, 1973a). Bone collagen from middiaphyseal regions of tibiae and femora from foetal calves (5-6 months) was prepared in a similar manner.

The demineralized collagen was reacted with $\mathrm{NaB}^{3} \mathrm{H}_{4}$ (New England Nuclear Corp., Boston, Mass., U.S.A.) for $45 \mathrm{~min}$ in $0.1 \mathrm{M}$-sodium phosphate, $\mathrm{pH} 7.4$, at a ratio of $3 \mathrm{mg}$ of $\mathrm{NaBH}_{4}$ to $100 \mathrm{mg}$ of collagen. For analyses of ${ }^{3} \mathrm{H}$ radioactivity in $\mathrm{CNBr}$ peptides separated by disc electrophoresis, about $5 \mathrm{mg}$ of collagen was reduced with $\mathrm{NaB}^{3} \mathrm{H}_{4}$ (sp. radioactivity, $200 \mathrm{Ci} / \mathrm{mol}$ ); a lower specific radioactivity (usually $1 \mathrm{Ci} / \mathrm{mol}$ ) was used for reduction before other analyses. After reduction, the suspension was adjusted to $\mathrm{pH} 3.0-4.0$ by addition of acetic acid, and the collagen was thoroughly washed with water.

\section{Cleavage with $\mathrm{CNBr}$}

$\mathrm{NaBH}_{4}$-treated, demineralized bone powder was stirred in $70 \%(\mathrm{v} / \mathrm{v})$ formic acid under $\mathrm{N}_{2}$ at $30^{\circ} \mathrm{C}$ for $4 \mathrm{~h}$ with a 150:1 molar ratio of $\mathrm{CNBr} /$ methionine. The resulting solution was diluted tenfold with water and freeze-dried.

Disc electrophoresis of $\mathrm{CNBr}$ peptides in sodium dodecyl sulphate-polyacrylamide gels

The method of Furthmayr \& Timpl (1971) was followed by using $7.5 \%(\mathrm{w} / \mathrm{v})$ acrylamide in $10 \mathrm{~cm}$ gels. Gels were stained with Coomassie Brilliant Blue or serially sliced (Gilson Instruments Co., Gel Fractionator) for measurement of ${ }^{3} \mathrm{H}$-radioactivity. The minced gel slices $(0.5 \mathrm{~mm})$ were treated with $0.5 \mathrm{ml}$ of Protosol (New England Nuclear Corp.) in capped scintillation vials for $4 \mathrm{~h}$ and, after acidifying the digests by addition of $0.05 \mathrm{ml}$ of acetic acid, $10 \mathrm{ml}$ of Aquasol (New England Nuclear Corp.) was added and shaken vigorously for $30 \mathrm{~min}$ to give a clear solution.

The molecular weights of cross-linked peptides were assessed from a calibration plot of the distance travelled in the gel versus the logarithm of the molecular weight of the known $\mathrm{CNBr}$ peptides of collagen. These peptides were identified in the stained gels by comparison with previous analyses (Furthmayr \& Timpl, 1971). Although molecular weights below about 15000 cannot be estimated reliably by this technique alone (Williams \& Gratzer, 1971), the elution position of the peptides on molecular-sieve chromatography in comparison with the $\mathrm{CNBr}$ peptides of known size confirmed the estimated values.

\section{Molecular-sieve chromatography of $\mathrm{CNBr}$ peptides}

Complete $\mathrm{CNBr}$ digests of reduced collagen from chicken bone (about $40 \mathrm{mg}$ ) were fractionated on a column $(200 \mathrm{~cm} \times 2 \mathrm{~cm})$ of Bio-Gel agarose $(1.5 \mathrm{~m}$, 200-400 mesh; Bio-Rad Laboratories, Richmond, Calif., U.S.A.), and eluted with $1 \mathrm{M}-\mathrm{CaCl}_{2}-0.05 \mathrm{M}-$ Tris- $\mathrm{HCl}, \mathrm{pH} 7.4$, at a flow rate of $10 \mathrm{ml} / \mathrm{h}$.

The CNBr peptides isolated by phosphocellulose chromatography were further resolved by elution from a column $(100 \mathrm{~cm} \times 1.6 \mathrm{~cm})$ of Bio-Gel P-150 (100-200 mesh) in $1 \mathrm{M}-\mathrm{CaCl}_{2}-0.05 \mathrm{M}$-Tris $-\mathrm{HCl}$, $\mathrm{pH} 7.4$, at a flow rate of $12 \mathrm{ml} / \mathrm{h}$. The peptide fractions eluting from this column were desalted by gel filtration on a column of Bio-Gel P-2 (100-200 mesh) and eluted with $0.1 \mathrm{M}$-acetic acid. 


\section{Chromatography of $\mathrm{CNBr}$ peptides on phospho- cellulose}

The fraction of cross-linked peptide isolated by gel filtration on agarose was applied to a column $(15 \mathrm{~cm} \times 2 \mathrm{~cm}$ ) of phosphocellulose (Whatman P-11; W. and R. Balston, Maidstone, Kent, U.K.) at $42^{\circ} \mathrm{C}$ and eluted with a linear gradient of $0-0.5 \mathrm{M}-$ $\mathrm{NaCl}$ in $800 \mathrm{ml}$ of $1 \mathrm{~mm}$-sodium acetate, $\mathrm{pH} 3.6$, at a flow rate of $100 \mathrm{ml} / \mathrm{h}$. The column was then flushed with starting buffer containing $1 \mathrm{M}-\mathrm{NaCl}$ and $8 \mathrm{M}$ urea, and the peptides in the voided fraction were collected.

\section{Digestion with bacterial collagenase}

This was carried out as previously described on samples $(1 \mathrm{~g})$ of demineralized bone collagen by using relatively crude bacterial collagenase (Schwarz/ Mann, Orangeburg, N.Y., U.S.A.) (Eyre \& Glimcher, 1973a).

Molecular-sieve chromatography of the collagenase digest of bone collagen

Cross-linked peptides in the collagenase digest of bone collagen were partially resolved by elution from a column $(2.6 \mathrm{~cm} \times 30 \mathrm{~cm})$ of Bio-Gel P-2 (100200 mesh). The void fraction recovered from this column was then applied to a column $(1.6 \mathrm{~cm} \times 90 \mathrm{~cm})$ of Bio-Gel P-10 (200-400 mesh). Both columns were eluted with $0.1 \mathrm{M}$-acetic acid.

\section{Ion-exchange chromatography of collagenase peptides on phosphocellulose}

The partially purified, cross-linked peptides were fractionated by elution from a column $(2 \mathrm{~cm} \times 15 \mathrm{~cm})$ of phosphocellulose (Whatman, P-11) at $42^{\circ} \mathrm{C}$ with a linear gradient of $0.2-0.6 \mathrm{M}-\mathrm{NaCl}$ in $800 \mathrm{ml}$ of $1 \mathrm{~mm}$ sodium acetate, $\mathrm{pH} 3.6$, at a flow rate of $100 \mathrm{ml} / \mathrm{h}$.

\section{Purification of peptides on Bio-Gel P-6}

The cross-linked collagenase peptide in the major peak of ${ }^{3} \mathrm{H}$ radioactivity that eluted from the phosphocellulose column near the end of the $\mathrm{NaCl}$ gradient was finally purified by elution from a column $(1.6 \mathrm{~cm} \times 100 \mathrm{~cm})$ of Bio-Gel P-6, 200-400 mesh, in $0.1 \mathrm{M}$-acetic acid at a flow rate of $20 \mathrm{ml} / \mathrm{h}$.

\section{Oxidation with periodate}

The peptide containing the reduced cross-linking compounds was dissolved in $1 \mathrm{ml}$ of $0.02 \mathrm{M}$-acetic acid and reacted with $1 \mathrm{ml}$ of $0.02 \mathrm{M}$-sodium metaperiodate in the dark at $25^{\circ} \mathrm{C}$ for $3 \mathrm{~h}$. Excess of periodate was destroyed by addition of one drop of ethylene glycol, and aldehydic reaction products were reduced with
$\mathrm{NaBH}_{4}$ after addition of $0.1 \mathrm{M}$-phosphate buffer, pH 7.4 (Bailey et al., 1970b). The reaction mixture was adjusted to pH3-4 with acetic acid, evaporated to dryness and applied to the Bio-Gel P-6 column (see above). The region of effluent containing the two partially resolved peptide fragments (Eyre \& Glimcher, 1973b) was pooled, dried and hydrolysed in $6 \mathrm{M}-\mathrm{HCl}$ for amino acid analysis.

\section{Amino acid analysis}

Peptides were hydrolysed in $6 \mathrm{M}-\mathrm{HCl}$ under $\mathrm{N}_{2}$ in a sealed tube at $105^{\circ} \mathrm{C}$ for $24 \mathrm{~h}$. Phenol $(10 \mathrm{~mm})$ was included in the $\mathrm{HCl}$ to prevent loss of tyrosine during hydrolysis. Amino acid compositions were determined on an automated amino acid analyser with a single column eluted by a complex gradient. The crosslinking compounds, HylOHNle and HylNle, were eluted as separate peaks between $\mathrm{NH}_{3}$ and hydroxylysine in this system. By using a split-stream device, $50 \%$ of the column effluent could be monitored for ${ }^{3} \mathrm{H}$ radioactivity by mixing it with Aquasol (New England Nuclear Corp.) and pumping the mixture through a Teflon coil in a specially constructed well of a scintillation counter (Intertechnique Instruments, Model SL 20) (Eyre, 1973). The reduced cross-links, HylOHNle and HylNle, were quantitated in large samples of hydrolysed collagen by chromatography on the $60 \mathrm{~cm}$ analyser column eluted at $54^{\circ} \mathrm{C}$ with $0.35 \mathrm{M}$-sodium citrate, $\mathrm{pH} 5.2$, and by reacting the effluent with ninhydrin.

\section{Results}

\section{Fractionation of $\mathrm{CNBr}$ peptides}

In the following experiments, reducible cross-links were labelled by reduction with $\mathrm{NaB}^{3} \mathrm{H}_{4}$ before digestion of the bone collagen with $\mathrm{CNBr}$ in $70 \%$ (v/v) formic acid. When, however, a $\mathrm{CNBr}$ digest of nonreduced bone collagen was treated with $\mathrm{NaB}^{3} \mathrm{H}_{4}$, labelled hydroxylysinohydroxynorleucine was found in about the same concentration as in the reduced, native collagen (Fig. 1), showing that the dehydro form of this compound is not disrupted in relatively strong acid or during degradation of the collagen by $\mathrm{CNBr}$. A fraction of the other reducible cross-link in bone collagen, dehydro-HylNle, also appeared to resist destruction during digestion of the collagen with CNBr (Fig. 1).

After labelling the reducible cross-links in bone collagen by reduction with $\mathrm{NaB}^{3} \mathrm{H}_{4}$, a profile of the molecular sizes of the major cross-linked $\mathrm{CNBr}$ peptides was derived by disc electrophoresis of the peptides in sodium dodecyl sulphate-polyacrylamide gels and then by measuring ${ }^{3} \mathrm{H}$ radioactivity in serial slices of the polyacrylamide gel. By this technique, chicken bone collagen gave a different 


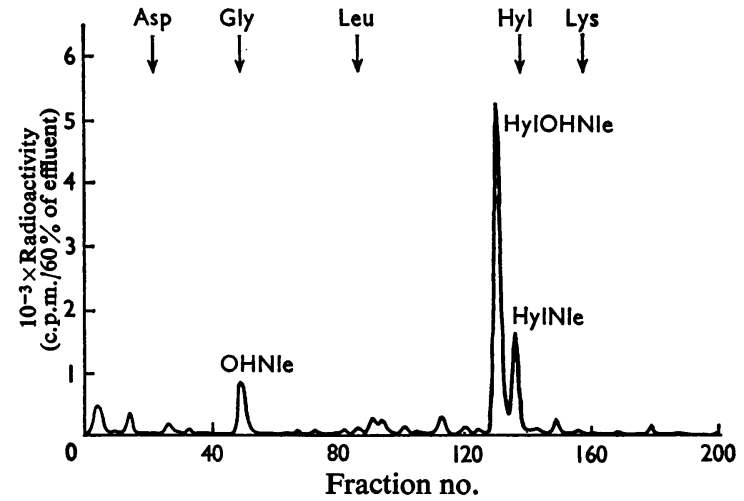

Fig. 1. Ion-exchange column chromatography of ${ }^{3} \mathrm{H}$ labelled cross-linking components

These were derived by reduction with $\mathrm{NaB}^{3} \mathrm{H}_{4}$ $(10 \mathrm{Ci} / \mathrm{mol})$ of the peptides resulting from $\mathrm{CNBr}$ digestion of chicken bone collagen. Peptides were reacted with $\mathrm{NaB}^{3} \mathrm{H}_{4}$ as a solution in $0.1 \mathrm{M}$-phosphate, pH 7.4, and desalted on a column of Bio-Gel $\mathrm{P}-2$. The peptide mixture was hydrolysed in $3 \mathrm{M}-\mathrm{HCl}$ for $48 \mathrm{~h}$ at $105^{\circ} \mathrm{C}$, and $10 \mathrm{mg}$ was applied to the column.

profile of tritiated cross-linked peptides from that of calf bone collagen (Plate 1). An obvious difference between the peptides from the two species is the presence of a major zone of ${ }^{3} \mathrm{H}$ radioactivity migrating near the $\alpha 1 \mathrm{CB} 3$ peptide in the electrophoretic pattern derived from chicken bone collagen, and corresponding to a molecular size of about 10000 to 13000 . This peak of activity was not present on analysis of peptides derived from calf bone collagen (Plate 1), nor in $\mathrm{CNBr}$ peptides derived from samples of human bone collagen analysed by the same technique. Compared with the profile for chicken bone collagen, more of the total ${ }^{3} \mathrm{H}$ radioactivity, and hence of cross-linked peptides, was detected in the peptide profiles of calf and human bone collagens in the region of the polyacrylamide gel containing the $\mathrm{CNBr}$ peptides $\alpha 1 \mathrm{CB} 7, \alpha 1 \mathrm{CB} 8$ and $\alpha 2 \mathrm{CB} 4$, and corresponding to a molecular weight of about 20000 to 25000 . Another major band of ${ }^{3} \mathrm{H}$ radioactivity was detected on electrophoresis of chicken bone collagen in the region of the uncleaved peptide, $\alpha 1$ CB3-7 (Plate 1). This peak was also absent from the profiles of calf and human $\mathrm{CNBr}$ peptides, being replaced by extra ${ }^{3} \mathrm{H}$ radioactivity in the region of the gel that would contain collagen $\mathrm{CNBr}$ peptides having a molecular weight about 10000 larger.

Molecular-sieve chromatography on agarose confirmed the presence in the $\mathrm{CNBr}$ digest of reduced chicken bone collagen of a major ${ }^{3} \mathrm{H}$-labelled, cross- linked fraction having a molecular weight of about 10000 (the peak marked with a bar in Plate 2). Disc electrophoresis of peptides recovered from this region of the chromatogram showed several stained bands, two of which migrated in the polyacrylamide gels where the ${ }^{3} \mathrm{H}$ radioactivity was previously detected after gel-slicing (Plate 2). The slower, and probably larger, of these two peptides was tentatively identified as peptide $\alpha 1 \mathrm{CB} 3$. In an attempt to purify the crosslinked peptide, the material partially separated on the agarose column was chromatographed on phosphocellulose by elution with a salt gradient (not shown). Some ${ }^{3} \mathrm{H}$ radioactivity did elute with the gradient, but not as a discrete peak or peaks; nor were the recoveries of ${ }^{3} \mathrm{H}$ radioactivity from the column consistent in several experiments. It appeared that the cross-linked peptides were precipitating on the phosphocellulose column, thus preventing their elution, even with $1 \mathrm{M}-\mathrm{NaCl}$. However, elution of the column with $1 \mathrm{M}-\mathrm{NaCl}$ in $8 \mathrm{M}$-urea did remove the bound peptides containing the remaining ${ }^{3} \mathrm{H}$ radioactivity. Peptide peaks that were detected by u.v. absorption at $230 \mathrm{~nm}$ during gradient elution of the phosphocellulose column were identified by their disc electrophoretic mobilities and amino acid compositions as the single-chain peptides $\alpha 1 \mathrm{CB} 3$, $\alpha 1 \mathrm{CB} 6 \mathrm{~A}, \alpha 1 \mathrm{CB} 7$ and $\alpha 1 \mathrm{CB} 8$ (Miller et al., 1969). However, the peptide $\alpha 1 \mathrm{CB} 6 \mathrm{~B}$ was not detected by amino acid analysis in any of the fractions eluted with the $\mathrm{NaCl}$ gradient.

In a final attempt to isolate a pure $\mathrm{CNBr}$ peptide containing a cross-link, the radioactive peptides that were stripped from the phosphocellulose column by urea were chromatographed on Bio-Gel P-150 (Fig. 2). The major peak of radioactivity chromatographed in the position expected for a collagen peptide of about 10000 molecular weight. Amino acid analysis of the peptide recovered from the region of effluent corresponding to this peak revealed the reduced cross-links, HylOHNle and HylNle, but assuming a molar colour yield with ninhydrin twice that of leucine, only $20 \%$ of the amount of these cross-linking compounds was detected compared with the amount that would be expected for a peptide of 10000 molecular weight that contained one cross-linking residue per molecule (Table 1). Disc electrophoretic analysis revealed one broad band of stained peptide material. The amino acid composition which includes almost one residue of 3-hydroxyproline, but only 0.2 residue of homoserine, indicated that the major $\mathrm{CNBr}$ peptide in the material was the carboxy-terminal peptide $\alpha 1$ CB6B.

However, the amino acid composition of peptide $\alpha 1$ CB6B shown in Table 1 is of the peptide isolated from the $\alpha 1$ chain of acid-soluble chicken bone collagen (Miller, 1969), which has lost a $C$-terminal extra-helical sequence (Eyre \& Glimcher, 1972b). Although the composition of the whole additional 

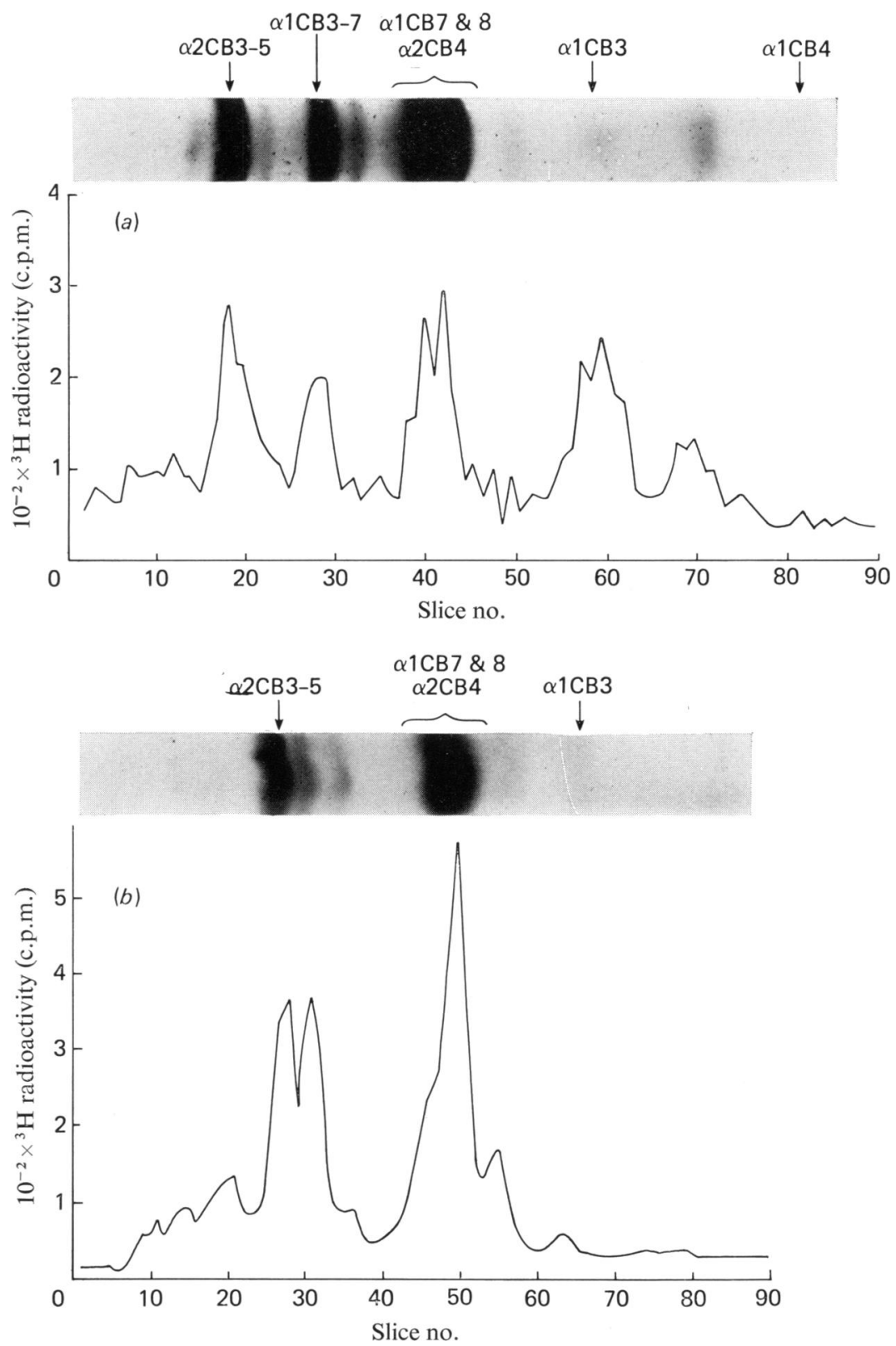

EXPLANATION OF PLATE I

Disc electrophoresis in sodium dodecyl sulphate-polyacrylamide gels of $\mathrm{CNBr}$ digests of $\mathrm{NaB}^{3} \mathrm{H}_{4}$-treated bone collagen

For each analysis one gel was stained with Coomassie Brilliant Blue and another, unstained gel, was serially sliced $(0.5 \mathrm{~mm})$ for measurement of ${ }^{3} \mathrm{H}$ radioactivity in the peptides. $\mathrm{CNBr}$ digest $(100 \mu \mathrm{g})$ was applied to each gel. (a) $\mathrm{CNBr}$ digest of chicken bone collagen, (b) $\mathrm{CNBr}$ digest of calf bone collagen. The positions of various peptides are marked on the gel scan. 


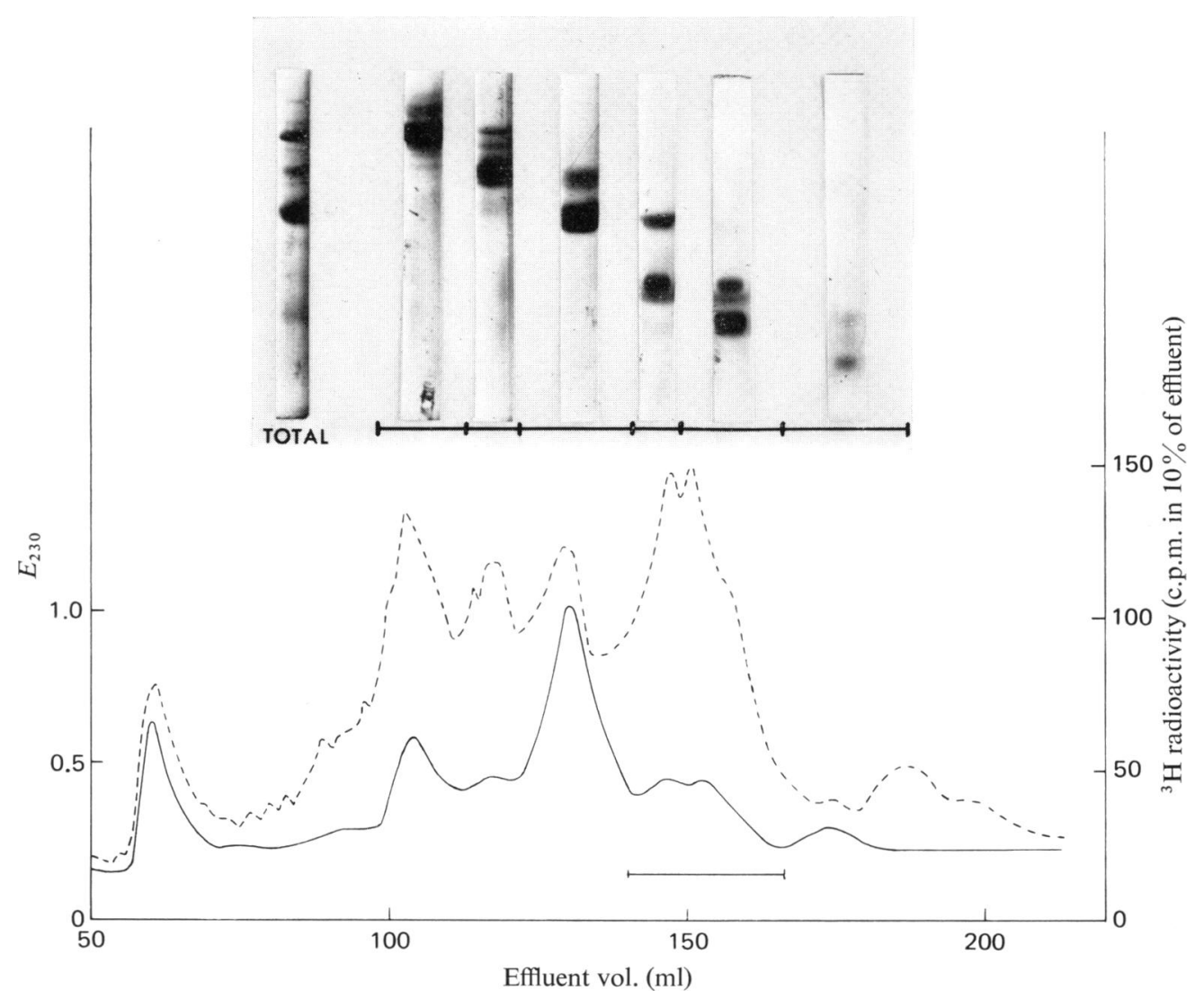

EXPLANATION OF PLATE 2

Molecular-sieve chromatography of a $\mathrm{CNBr}$ digest of $\mathrm{NaB}^{3} \mathrm{H}_{4}$-treated chicken bone collagen on Bio-Gel Agarose

The column $(1.5 \mathrm{~m}, 200-400$ mesh; $200 \mathrm{~cm} \times 2 \mathrm{~cm})$, was eluted with $1 \mathrm{M}-\mathrm{CaCl}_{2}-0.05 \mathrm{M}-\mathrm{Tris}-\mathrm{HCl}, \mathrm{pH} 7.4$, at a flow rate of $10 \mathrm{ml} / \mathrm{h}$. The inset shows the results of disc electrophoretic analysis in sodium dodecyl sulphatepolyacylamide gel of peptides isolated after dialysis against water of the regions of column effluent marked by the bars. Peptides in the region marked by the bar on the chromatograph were taken for ion-exchange chromatography on phosphocellulose.,$- E_{230} ;----,{ }^{3} \mathrm{H}$ radioactivity. 


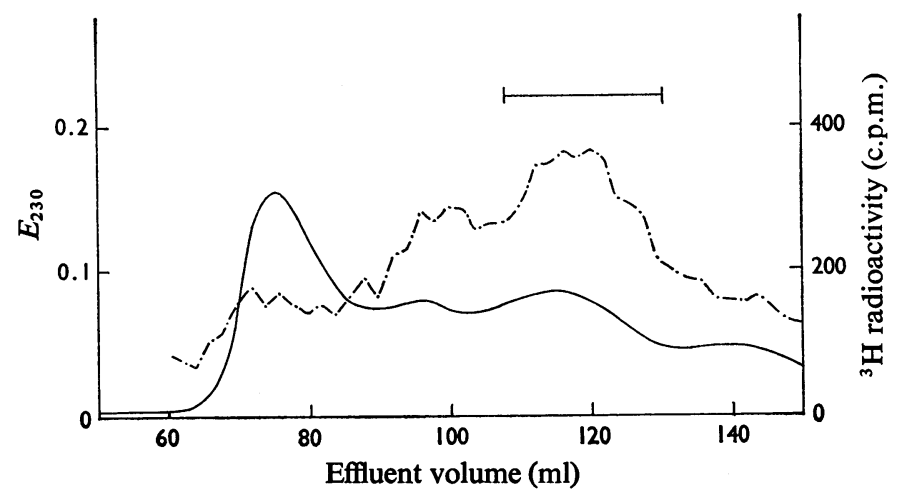

Fig. 2. Molecular-sieve chromatography on Bio-Gel P-150 (100-200 mesh; $100 \mathrm{~cm} \times 1.6 \mathrm{~cm})$ of the CNBr peptide fraction of chicken bone collagen recovered from the phosphocellulose column by elution with $1 \mathrm{M}-\mathrm{NaCl}$ in $8 \mathrm{M}$-urea

The peptide in the region of column effluent marked by a bar was desalted on Bio-Gel P-2 before hydrolysis in acid and amino acid analysis.,$- E_{230} ;-.-.-,{ }^{3} \mathrm{H}$ radioactivity.

Table 1. Amino acid composition of a $\mathrm{CNBr}$ peptide that contains cross-links from $\mathrm{NaBH}_{4}$-treated chicken bone collagen

The values in parentheses denote the measured values from which nearest integers are derived. The composition of the peptide fraction isolated in the present study is compared with the sum of published analyses for peptide $\alpha 1 \mathrm{CB} 6 \mathrm{~B}$ plus an extrahelical $C$-terminal sequence of $\alpha 1$.

Amino acid composition (residues/molecule)

\begin{tabular}{|c|c|c|c|}
\hline & Peptide & $\alpha 1 \mathrm{CB} 6 \mathrm{~B}^{*}$ & $C$-Terminal extrahelical region of $\alpha 1 \dagger$ \\
\hline 3Нyp & $1(0.7)$ & 1 & - \\
\hline 4Hyp & $9(8.7)$ & 9 & 一 \\
\hline Asp & $5(4.7)$ & 3 & 2 \\
\hline Thr & $2(1.8)$ & 1 & - \\
\hline Ser & $6(5.8)$ & 5 & 1 \\
\hline Glu & $8(7.9)$ & 5 & 3 \\
\hline Pro & $11(10.8)$ & 13 & 3 \\
\hline Gly & $31(31.0)$ & 28 & 3 \\
\hline Ala & $9(9.4)$ & 6 & 1 \\
\hline Val & $2(2.0)$ & 2 & - \\
\hline Ile & $1(1.1)$ & 1 & - \\
\hline Leu & $3(2.6)$ & 3 & 2 \\
\hline Tyr & $1(0.8)$ & - & 1 \\
\hline HylOHNle & 0.13 & - & - \\
\hline HylNleł & 0.06 & - & - \\
\hline Hyl & 0.4 & 0.6 & - \\
\hline Lys & 2.1 & 1.4 & $1 \S$ \\
\hline His & $1(1.0)$ & 1 & 1 \\
\hline Arg & $4(4.2)$ & 4 & 1 \\
\hline Hse\| & 0.2 & - & - \\
\hline Total & 98 & 85 & 20 \\
\hline
\end{tabular}

Vol. 135 

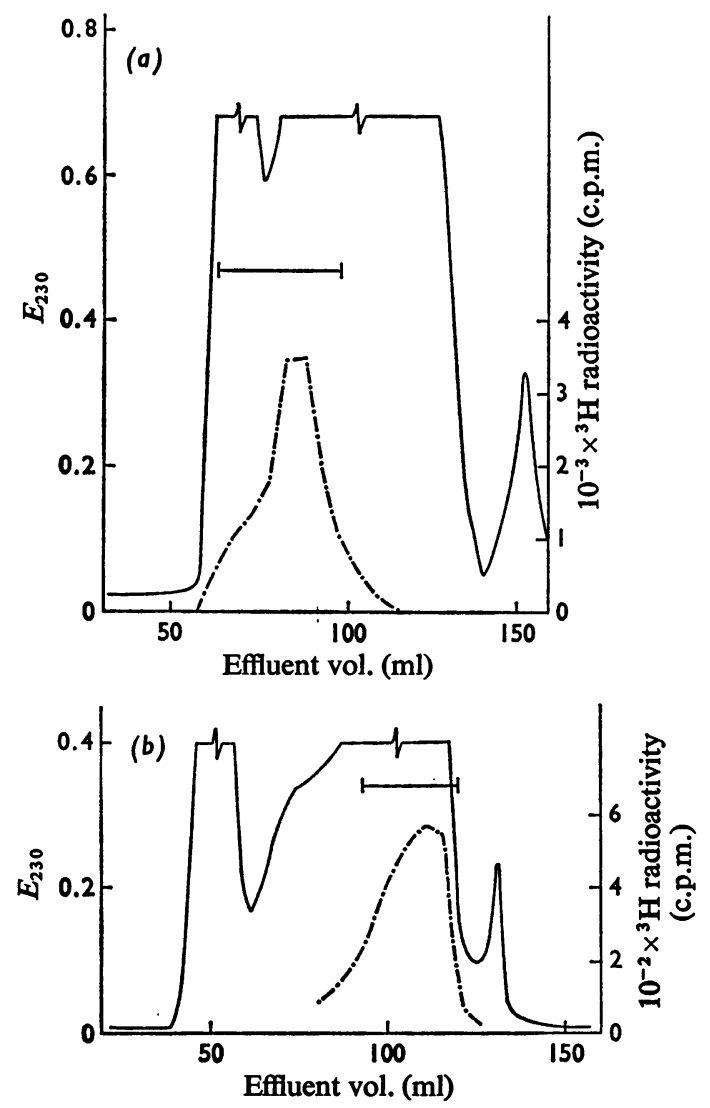

Fig. 3. Molecular-sieve chromatography of a collagenase digest of $1 \mathrm{~g}$ of $\mathrm{NaB}^{3} \mathrm{H}_{4}$-treated chicken bone collagen

(a) Elution of the complete digest from Bio-Gel P-2 $(100-200 \mathrm{mesh} ; 2.6 \mathrm{~cm} \times 30 \mathrm{~cm})$ in $0.1 \mathrm{M}$-acetic acid. Peptides in the column effluent marked by a bar were freeze-dried. (b) Elution of the peptides recovered from the Bio-Gel P-2 column from Bio-Gel P-10 (200-400 mesh; $1.6 \mathrm{~cm} \times 90 \mathrm{~cm})$ in $0.1 \mathrm{M}$-acetic acid. Peptides in the region of effluent marked by a bar were fractionated on phosphocellulose (Fig. 4). _ $E_{230} ;-.-\cdot-,{ }^{3} \mathrm{H}$ radioactivity.

sequence is not known for chicken bone collagen, it is apparently similar to that of calf skin collagen (Eyre \& Glimcher, 1972b), which is given in Table 1. The sum of this composition and that of peptide $\alpha 1 C B 6 B$ from acid-soluble bone collagen is similar to that found in the present preparation which probably contains peptide $\alpha 1 \mathrm{CB} 6 \mathrm{~B}$ that has the C-terminal extra-helical extension. The low recovery of the crosslinking amino acids and of homoserine suggests that

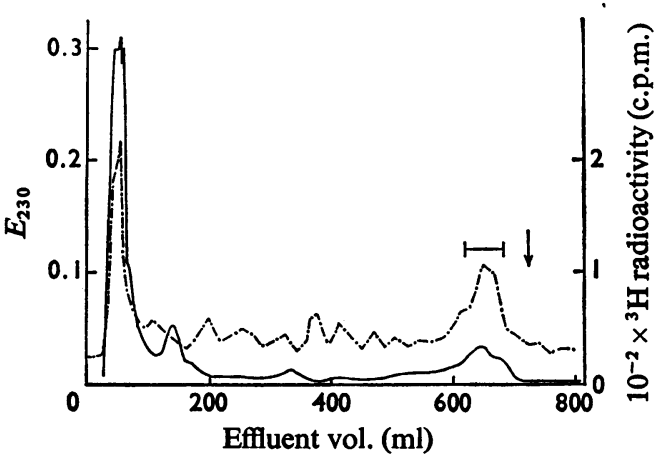

Fig. 4. Ion-exchange column chromatography on phosphocellulose of the collagenase peptides of chicken bone collagen isolated by gel filtration on Bio-Gel P-10 (Fig. 3)

The phosphocellulose column $(2 \mathrm{~cm} \times 15 \mathrm{~cm})$ was eluted at $42^{\circ} \mathrm{C}$ with a linear gradient of $0.2-0.6 \mathrm{M}$ $\mathrm{NaCl}$ in a total volume of $800 \mathrm{ml}$ of $1 \mathrm{mM}$-sodium acetate, $\mathrm{pH} 3.6$, at a flow rate of $100 \mathrm{ml} / \mathrm{h}$. At the arrow the column was eluted with $1 \mathrm{M}-\mathrm{NaCl}$ in starting buffer. The fractions marked by a bar were further analysed by molecular-sieve chromatography on Bio-Gel P-6. —, $E_{230} ;-\cdot-\cdot-,{ }^{3} \mathrm{H}$ radioactivity.

the preparation is a mixture of free $\alpha 1 \mathrm{CB} 6 \mathrm{~B}$ with a smaller amount of peptide $\alpha 1 \mathrm{CB} 6 \mathrm{~B}$ cross-linked to a short $\mathrm{CNBr}$ peptide that does not significantly increase the molecular size.

\section{Fractionation of collagenase peptides}

About one-third of the total ${ }^{3} \mathrm{H}$ radioactivity incorporated into demineralized chicken bone by $\mathrm{NaB}^{3} \mathrm{H}_{4}$ was recovered by molecular-sieve chromatography of a collagenase digest on columns of Bio-Gel P-2 and Bio-Gel P-10 (Fig. 3), in peptides which accounted for $2 \%$ of the collagen by weight. Thus, the cross-linked peptides had been concentrated approximately 15 -fold in the recovered peptide fraction. Chromatography of this material on phosphocellulose (Fig. 4) gave two major peaks of ${ }^{3} \mathrm{H}$ radioactivity. One of these, the void peak, could be resolved into several radioactive peptides by rechromatography on the phosphocellulose column with a $\mathrm{NaCl}$ gradient starting at a lower concentration. None of these peptides was analysed in the present study. The peak of ${ }^{3} \mathrm{H}$ radioactivity eluting at the end of the $\mathrm{NaCl}$ gradient contained essentially one cross-linked peptide when purified by elution from Bio-Gel P-6 (Fig. 5 ), and was clearly the major peptide in the digest that contained reduced cross-links. This peptide had an identical amino acid composition, apart from the relative proportion of the reduced cross-linking 
amino acids, HylOHNle and HylNle, to a peptide recently isolated by a similar procedure from calf bone collagen (Eyre \& Glimcher, 1973b). After cleavage of the cross-links in the peptide by oxidation with $\mathrm{NaIO}_{4}$ and reduction of the reaction products with non-radioactive $\mathrm{NaBH}_{4}$, hydroxylysine and hydroxynorvaline were recovered by amino acid analysis (Table 2). As previously found with the peptide from calf bone collagen (Eyre \& Glimcher, $1973 b$ ), most of the ${ }^{3} \mathrm{H}$ radioactivity originally incorporated into the peptide by reduction of the cross-link with $\mathrm{NaB}^{3} \mathrm{H}_{4}$ remained associated with the peptide chains that were released after cleavage of the crosslink with $\mathrm{NaIO}_{4}$, and was recovered as radioactive hydroxynorvaline and chlornorvaline (derived from hydroxynorvaline on hydrolysis in $\mathbf{H C l}$ ) on amino acid analysis. After hydrolysis of the intact crosslinked peptide in $2 \mathrm{M}-\mathrm{KOH}$, HylOHNle and HylNle were not detected on the amino acid analyser, instead new ninhydrin-positive peaks with coincident ${ }^{3} \mathrm{H}$ radioactivity appeared in the chromatogram, the major one eluting just before $\mathrm{NH}_{3}$.

These findings indicate that most of the tritiated cross-links in the peptide fraction from chicken bone collagen had derived by $\mathrm{NaB}^{3} \mathrm{H}_{4}$ reduction of the keto-amine-rearranged forms of the dehydro crosslinks. Scheme 1 illustrates the rearrangement from aldimine to keto-amine for dehydro-HylOHNle and the degradation of the reduced compound by periodate when the remaining hydroxyl group, the one not derived by reduction, is glycosylated. The recovery of hydroxylysine after oxidation of the cross-linked peptide with periodate and hydrolysis in acid suggests that hydroxylysyl residues whose

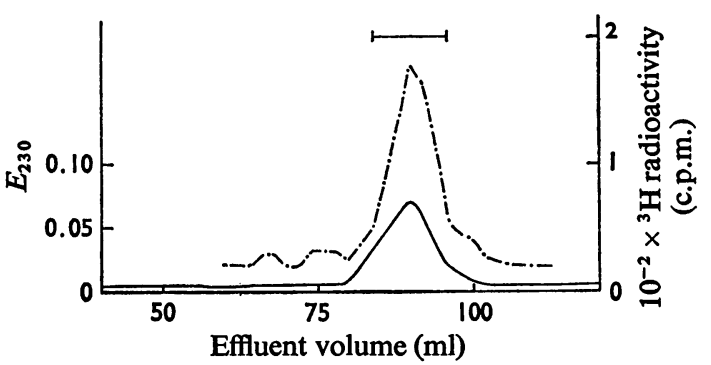

Fig. 5. Purification of the cross-linked collagenase peptide in the peak marked with a bar on the phosphocellulose chromatogram (Fig. 4), by molecular-sieve chromatography

A column of Bio-Gel P-6 (200-400 mesh; $1.6 \mathrm{~cm} \times$ $100 \mathrm{~cm}$ ) was eluted with $0.1 \mathrm{M}$-acetic acid at a flow rate of $20 \mathrm{ml} / \mathrm{h}$. - $E_{230} ;-\cdot-\cdot-,{ }^{3} \mathrm{H}$ radioactivity. The fractions marked by a bar were pooled and freezedried for amino acid analysis.

Table 2. Amino acid composition of the cross-linked peptide from collagenase-digested chicken bone collagen

The values in parentheses denote the measured values from which the nearest integers are derived. Samples of peptide for analysis were isolated from $(a) \mathrm{NaBH}_{4}$-treated collagen and $(b)$ untreated collagen.

Amino acid composition (residues/molecule)

$\begin{array}{ccc}\begin{array}{c}(a) \\ \text { Reduced collagen }\end{array} & \begin{array}{c}(b) \\ \text { Non-reduced collagen }\end{array} & \begin{array}{c}\text { Reduced peptide } \\ \text { +NaIO }\end{array} \text { + } \mathrm{NaBH}_{4} \\ 1(1.3) & 1(1.3) & 1.3 \\ - & - & 0.6 \\ 3(3.1) & 3(3.2) & 3.4 \\ 3(2.9) & 3(3.0) & 3.4 \\ 5(5.2) & 5(4.9) & 5.0 \\ 1(1.2) & 1(1.1) & 1.4 \\ 1(0.9) & 1(1.0) & 0.8 \\ 1(0.9) & 1(1.0) & 1.1 \\ 0.6 & 0.5 & - \\ 1(0.9) & 1(0.9) & - \\ 1(0.7) & - & - \\ (0.2) & - & 0.9 \\ 2(1.8) & 2(1.8) & 2.0 \\ 2 .(2.1) & 2(2.0) & 2.0\end{array}$

* The sum of hydroxynorvaline and chlornorvaline.

† Tyrosine content varied in different preparations of the peptide. Chains with 0,1 or 2 carboxy-terminal tyrosines apparently could be isolated (Eyre \& Glimcher, 1973b).

$\ddagger$ Assuming a molar colour yield twice that of leucine. 


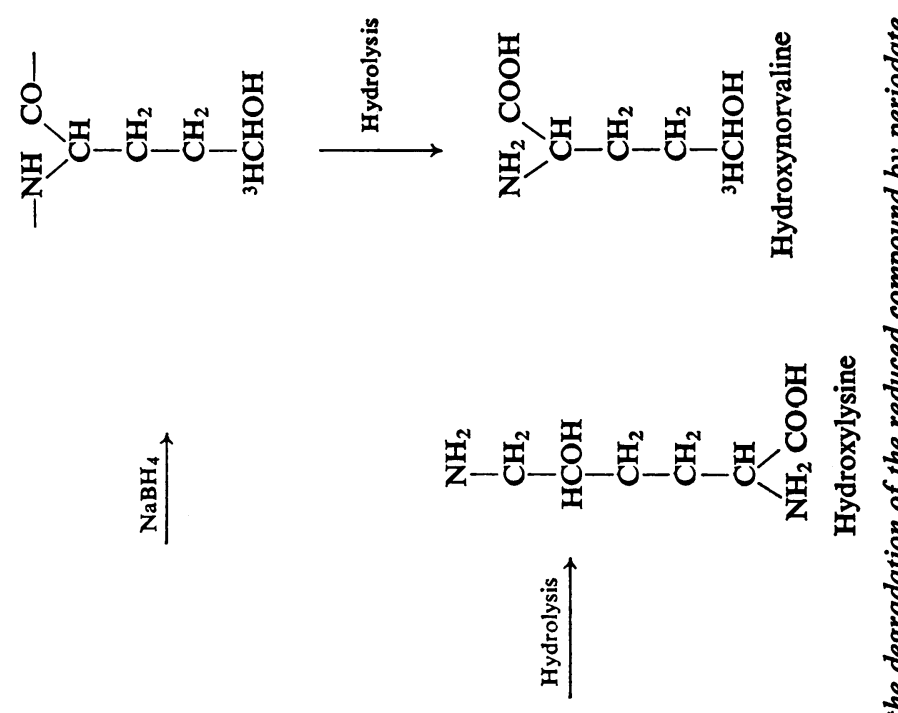

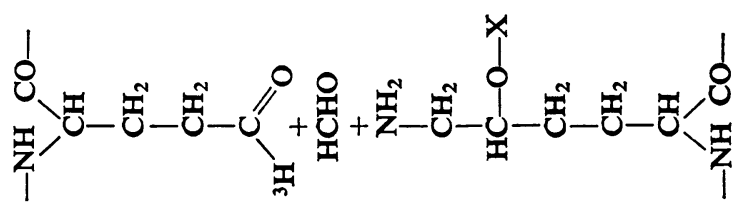

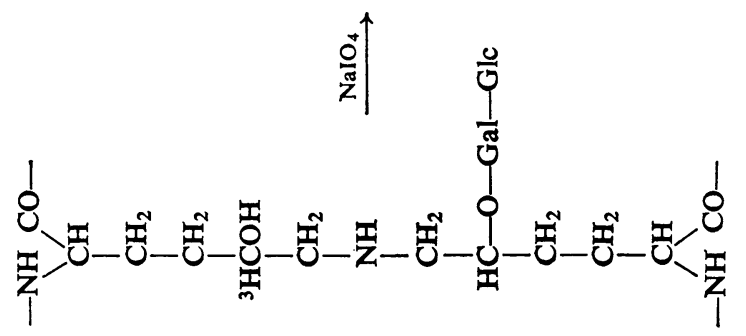

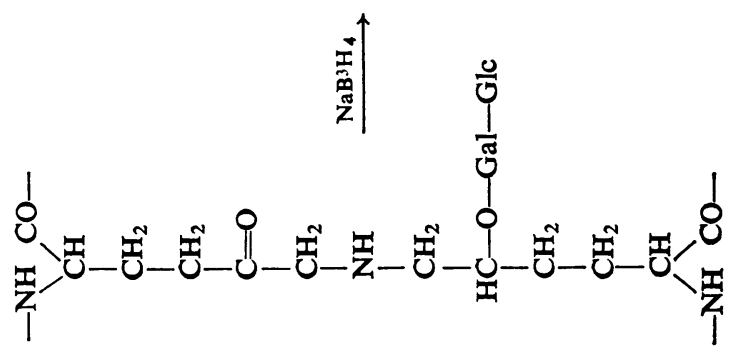

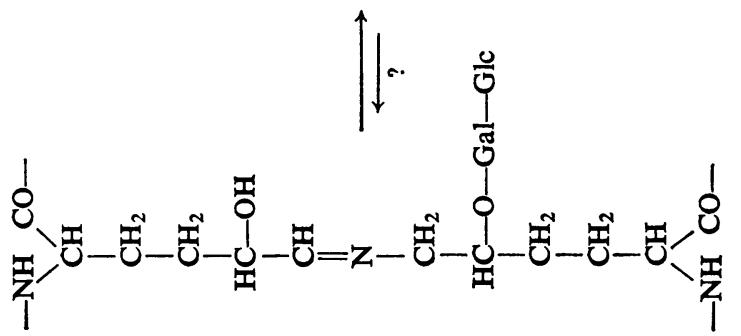



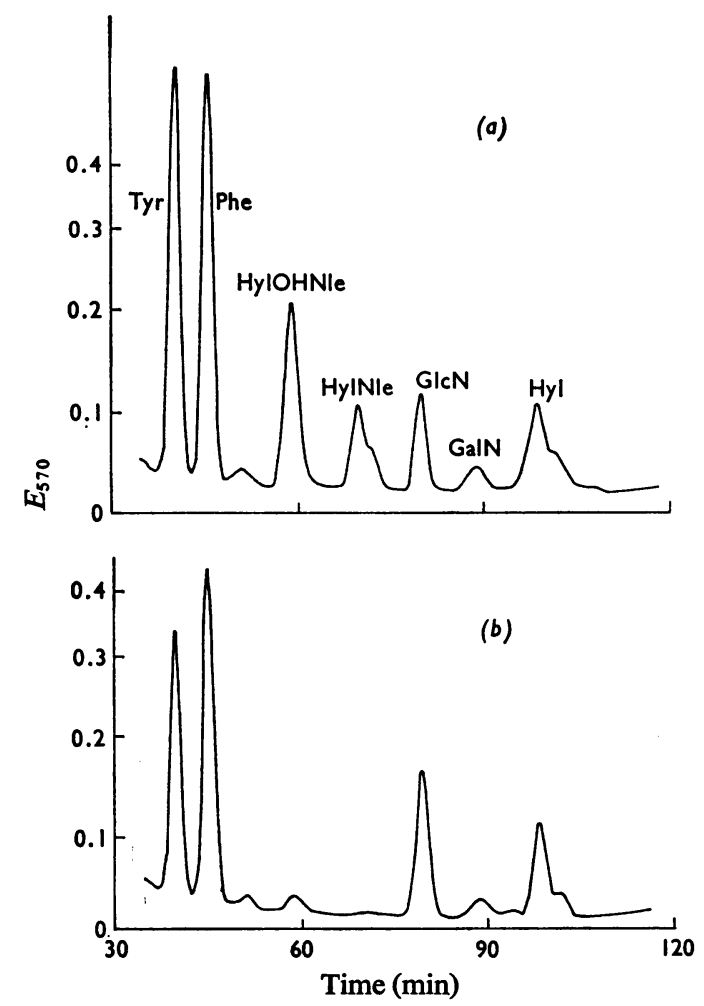

Fig. 6. Analysis of the reduced cross-linking amino acids, HylOHNle and HylNle, in an acid hydrolysate of the cross-linked peptides recovered by molecularsieve chromatography of a collagenase digest of chicken bone collagen (Fig. 3)

The $60 \mathrm{~cm}$ column of the amino acid analyser was eluted at $54^{\circ} \mathrm{C}$ with $0.35 \mathrm{M}$-sodium citrate, $\mathrm{pH} 5.2$, and the column effluent was reacted with ninhydrin. (a) Analysis of $1 \mathrm{mg}$ of peptides from $\mathrm{NaBH}_{4}$-treated chicken bone collagen. (b) Analysis of $1 \mathrm{mg}$ of peptides from untreated chicken bone collagen.

hydroxyl groups were substituted had participated in the biosynthesis of most of the cross-linking component in this peptide fraction. The normally susceptible side chains of such residues would resist cleavage by $\mathrm{NaIO}_{4}$ and acid hydrolysis would release free hydroxylysine from the $\mathrm{NaIO}_{4}$-treated crosslinks. The absence of HylOHNle and HylNle and the appearance of new ninhydrin-positive peaks with coincident ${ }^{3} \mathrm{H}$ radioactivity on analysis of the crosslinked peptide after hydrolysis in $2 \mathrm{M}-\mathrm{KOH}$, conditions under which glycosidic attachments to hydroxylysine are stable, suggest that most of the cross-linking compounds in this peptide were glycosylated, as found for the similar peptide from calf bone collagen (Eyre \& Glimcher, 1973b).

A collagenase digest of chicken bone collagen that had not been treated with $\mathrm{NaBH}_{4}$ was fractionated by a similar chromatographic procedure, by pooling appropriate regions of the various column effluents. A peptide with the same amino acid composition, apart from the absence of HylOHNle and HylNle, was recovered in a similar yield to the peptide isolated from the reduced bone collagen (Table 2). Some hydroxylysine and unidentified ninhydrin-positive peaks were now detected (not included in Table 2), which probably had derived by decomposition of the dehydro cross-links during acid hydrolysis. This conclusion was supported by the absence of the hydroxylysine and the unknown peaks on amino acid analysis of a sample of the peptide that had been treated with $\mathrm{NaBH}_{4}$ and then hydrolysed in acid, when HylOHNle and HylNle were recovered in the same concentrations as in the peptide isolated from reduced bone collagen.

Samples of the mixture of cross-linked peptides isolated from reduced chicken bone collagen and from non-reduced chicken bone collagen by elution from the Bio-Gel P-10 column (Fig. 3), were analysed directly for the cross-links HylOHNle and HylNle (Fig. 6). The result indicated that at the most only $6 \%$ of the HylOHNle and $2 \%$ of the HylNle detected in $\mathrm{NaBH}_{4}$-treated bone collagen could be present as the naturally reduced cross-links in the native bone collagen.

\section{Discussion}

The location of a major cross-linking site in the collagen molecule can be predicted from the results of disc electrophoretic analyses of the $\mathrm{CNBr}$ peptides of bone collagen that contain $\mathrm{NaBH}_{4}$-reduced cross-links. Thus the presence in a $\mathrm{CNBr}$ digest of $\mathrm{NaB}^{3} \mathrm{H}_{4}$-reduced chicken bone collagen of a ${ }^{3} \mathrm{H}$ labelled peptide with a molecular weight of about 10000 , and its absence from similar digests of calf and human bone collagens, probably reflects the basic difference between the $\mathrm{CNBr}$ peptides of chicken bone collagen and those of calf and human bone collagens. The $\mathrm{CNBr}$ peptides derived from $\alpha 1$ and $\alpha 2$ chains of calf skin collagen (Rauterberg \& Kühn, 1971; Fietzek et al., 1970) appear identical with those of human skin collagen (Click \& Bornstein, 1970) with respect to number and size. However, in skin and bone collagen of chicken there is an extra methionine residue in the carboxyterminal region of the $\alpha 1$ chain, giving two peptides, $\alpha 1 \mathrm{CB} 6 \mathrm{~A}$ and $\alpha 1 \mathrm{CB} 6 \mathrm{~B}$, in place of one peptide, $\alpha 1 \mathrm{CB} 6$, from calf and human collagens (Miller et al., 1969; Piez et al., 1969; Lane \& Miller, 1969; Kang et al., $1969 a, b)$. Now peptides $\alpha 1 C B 6 A$ and $\alpha 1$ CB6B (Miller et al., 1969; Kang et al., 1969a) are each about 
10000 molecular weight and peptide $\alpha 1 \mathrm{CB} 6$ is the sum of these at about 20000. An intermolecular cross-link between this carboxy-terminal region of an $\alpha 1$ chain and a relatively small $\mathrm{CNBr}$ peptide in another chain would explain the recovery of a cross-linked $\mathrm{CNBr}$ peptide of about 10000 molecular weight from chicken bone collagen, but its absence from a $\mathrm{CNBr}$ digest of calf or human bone collagens. The carboxy-terminus of the $\alpha 1$ chain of collagen is now known to be an important site of a crosslinking aldehyde (Stark et al., 1971), and peptide a1CB6 in rat (Rojkind et al., 1970; Kang, 1972), and bovine collagen (Volpin \& Veis, 1971), and peptide $\alpha 1 C B 6 B$ in chicken (Miller, 1969) were indicated as important participants of intermolecular cross-linking in collagen. In the present study the molecular size of the cross-linked $\mathrm{CNBr}$ peptide indicates that it consists of a relatively small $\mathrm{CNBr}$ peptide linked to peptides $\alpha 1 \mathrm{CB} 6 \mathrm{~A}$ or $\alpha 1 \mathrm{CB} 6 \mathrm{~B}$. From the known structure of chicken bone collagen the small CNBr peptide could be $\alpha 2 \mathrm{CB} 1$ or 2 , or $\alpha 1 \mathrm{CB} 1$, 4 or 5 , all of which, apart from peptide $\alpha 2 \mathrm{CB} 2$, are situated within or adjacent to the overlap region at the amino-terminus of the molecule. Scheme 2 illustrates the distribution of $\mathrm{CNBr}$ peptides in $\alpha 1$ and $\alpha 2$ chains and possible sites of intermolecular cross-linking between $\alpha 1$ chains of overlapping molecules packed in the Hodge-Petruska modification of a quarter-stagger arrangement (Hodge \& Petruska, 1963).

The amino acid composition of the cross-linked $\mathrm{CNBr}$ peptide that was detected by disc electro- phoresis and isolated by column chromatography, confirms that peptide $\alpha 1 C B 6 B$ is the main component. However, it would appear from the recovery of the cross-linking compounds that the peptide preparation consisted of about $20 \%$ of crosslinked peptide mixed with free peptide $\alpha 1 \mathrm{CB} 6 \mathrm{~B}$. The results support the previous observation that the $\alpha 1$ chain of chicken bone collagen loses a carboxyterminal region when extracted in non-denaturing solvents (Eyre \& Glimcher, 1972b), as do the $\alpha 1$ chains of calf and rat skin collagens (Rauterberg \& Kühn, 1971; Rauterberg et al., 1972). The amino acid composition suggests that the extrahelical sequence at the carboxy-terminus of chicken $\alpha 1$ is similar to that of calf $\alpha 1$.

The cross-linked peptide that was isolated from collagenase-digested bone collagen could derive from the same site in the molecule as the cross-linked $\mathrm{CNBr}$ peptide described above. It is noteworthy that the cross-linked peptide isolated from chicken bone collagen after digestion with crude collagenase has an almost identical amino acid composition with a comparable peptide isolated from calf bone collagen (Eyre \& Glimcher, 1973b), and presumably derives from a similar molecular site. It appeared from the composition of its component chains, that the peptide from calf bone collagen was derived from a sequence at the carboxy-terminus of an $\alpha 1$ chain that was crosslinked intermolecularly by a reducible bond to a glycosylated hydroxylysine residue located in the amino-terminal sequence of peptide $\alpha 1 C B 5$ in another $\alpha 1$ chain. In fact, assuming that the $\alpha 1$ chains of calf

$\mathbf{N}$
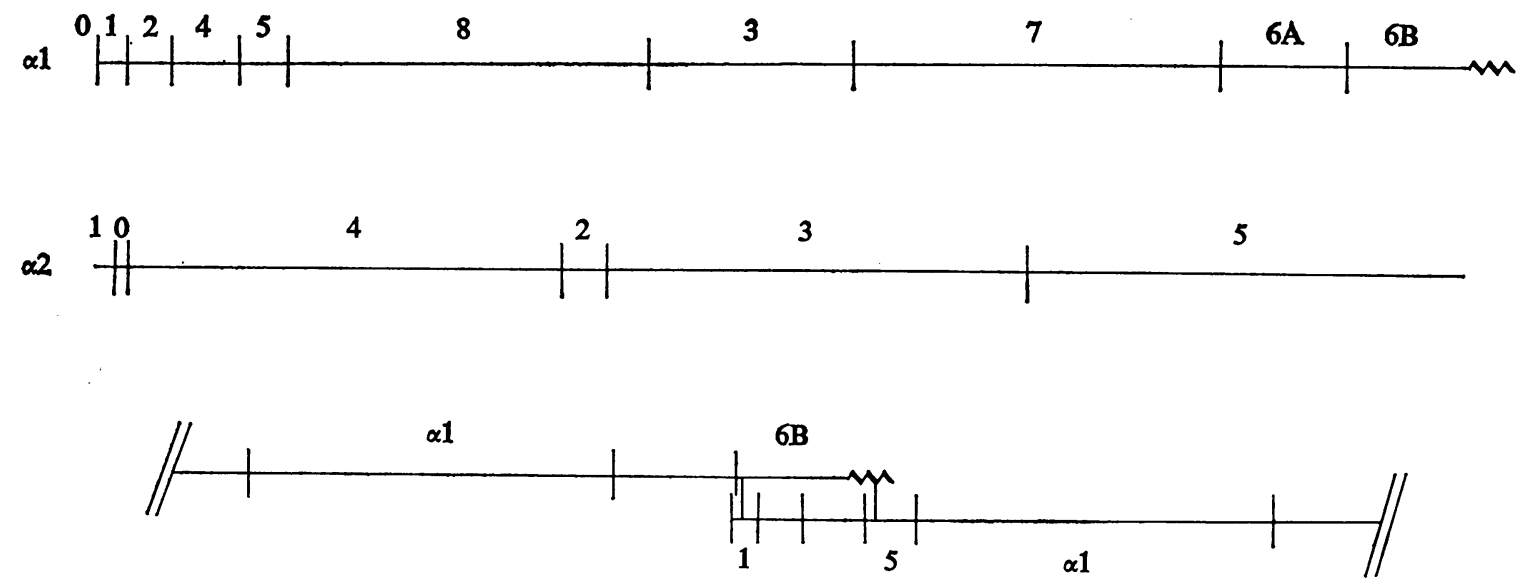

Scheme 2. Distribution of CNBr peptides in $\alpha 1$ and $\alpha 2$ chains of chicken bone collagen and two of the possible sites of intermolecular cross-linking between $\alpha 1$ chains of overlapping molecules packed in a quarter-stagger arrangement 
bone and skin have the same primary structure, the amino acid compositions of the peptide chains were so highly characteristic with all the rare amino acid constituents of collagen represented, that the peptides could not be ascribed to any other regions of the $\alpha 1$ chain (Eyre \& Glimcher, 1973b). However, the results do not rule out their origin in an $\alpha 2$ chain which may contain homologous sequences to the $\alpha 1$ chain.

The major reducible component of bone collagen, dehydro-HylOHNle, appears to be a stable intermolecular cross-link, even without reduction. It is not destroyed on digestion of collagen with $\mathrm{CNBr}$ in $70 \%$ formic acid, nor on digestion of the collagen to small peptides by bacterial collagenase. Rearrangement from an aldimine to a keto-amine form apparently explains the unusual stability of this major reducible compound of bone collagen (Tanzer, 1973; Eyre \& Glimcher, 1973b). Further, there is no evidence from the present data, nor from direct analyses of the reduced cross-links in several species of bone collagen at various stages of maturity (Brickley, 1972; D. R. Eyre, D. M. Brierley \& M. J. Glimcher, unpublished work), that reduction of these bonds occurs to a significant extent in vivo. However, since the number of reducible cross-links in collagen diminishes markedly with age and maturation of the tissues (Bailey et al., 1970a; Bailey \& Shimokomaki, 1971), it seems likely that the reducible bonds, including the keto-amine forms, are modified in vivo, but in a manner and to components as yet unidentified.

The authors thank Mrs. Florence Wang and Mrs. Kathy Heroux for their excellent technical assistance. This study was supported in part by a Grant from the National Institutes of Health (AM 15671).

\section{References}

Bailey, A. J. (1971) FEBS Lett. 18, 154-158

Bailey, A. J. \& Shimokomaki, M. S. (1971) FEBS Lett. 16, 86-88

Bailey, A. J., Peach, C. M. \& Fowler, L. J. (1970a) in The Chemistry and Molecular Biology of the Intercellular Matrix (Balàzs, E. A., ed.), vol. 1, pp. 385-404, Academic Press, London and New York

Bailey, A. J., Peach, C. M. \& Fowler, L. J. (1970b) Biochem. J. 117, 819-831

Brickley, D. M. (1972) Ph.D. Thesis, Boston University

Click, E. M. \& Bornstein, P. (1970) Biochemistry 9, 4699-4706

Davis, N. R. \& Bailey, A. J. (1971) Biochem. Biophys. Res. Commun. 45, 1416-1422
Eyre, D. R. (1973) Anal. Biochem. in the press

Eyre, D. R. \& Glimcher, M. J. (1971) Biochim. Biophys. Acta 243, 525-529

Eyre, D. R. \& Glimcher, M. J. (1972a) Proc. Nat. Acad. Sci. U.S. 69, 2594-2598

Eyre, D. R. \& Glimcher, M. J. (1972b) Biochem. Biophys. Res. Commun. 48, 720-726

Eyre, D. R. \& Glimcher, M. J. (1973a) Biochim. Biophys. Acta 295, 301-307

Eyre, D. R. \& Glimcher, M. J. (1973b) Biochem. Biophys. Res. Commun. 52, 663-671

Fietzek, P. P., Münch, M., Breitkreutz, Z. \& Kühn, K. (1970) FEBS Lett. 9, 229-231

Furthmayr, H. \& Timpl, R. (1971) Anal. Biochem. 41, 510-516

Gallop, P. M., Blumenfeld, O. O. \& Seifter, S. (1972) Annu. Rev. Biochem. 41, 617-672

Hodge, A. J. \& Petruska, J. A. (1963) in Aspects of Protein Structure (Ramachandran, G. N., ed.), p. 289, Academic Press, London and New York

Kang, A. H. (1972) Biochemistry 11, 1828-1835

Kang, A. H., Piez, K. A. \& Gross, J. (1969a) Biochemistry 8, 1506-1514

Kang, A. H., Igarashi, S. \& Gross, J. (1969b) Biochemistry 8, 3200-3204

Lane, J. M. \& Miller, E. J. (1969) Biochemistry 8, 2134 2139

Mechanic, G., Gallop, P. M. \& Tanzer, M. L. (1971) Biochem. Biophys. Res. Commun. 45, 644-653

Miller, E. J. (1969) Fed. Proc. Fed. Amer. Soc. Exp. Biol. 28, 1839-1845

Miller, E. J., Lane, J. M. \& Piez, K. A. (1969) Biochemistry 8, 30-39

Piez, K. A., Miller, E. J., Lane, J. M. \& Butler, W. T. (1969) Biochem. Biophys. Res. Commun. 37, 801-805

Rauterberg, J. \& Kühn, K. (1971) Eur. J. Biochem. 19, 398-407

Rauterberg, J., Fietzek, P., Rexrodt, R., Becker, U., Stark, M. \& Kühn, K. (1972) FEBS Lett. 21, 75-79

Rojkind, M., Hamabata, A., Gonzalez, E. \& Rendón, G. (1970) in The Chemistry and Molecular Biology of the Intercellular Matrix (Balàzs, E. A., ed.), vol. 1, pp. 293303, Academic Press, London and New York

Stark, M., Rauterberg, J. \& Kühn, K. (1971) FEBS Lett. 13, 101-104

Tanzer, M. L. (1973) Science 180, 561-565

Tanzer, M. L., Housley, T., Berube, L., Fairweather, R., Franzblau, C. \& Gallop, P. M. (1973) J. Biol. Chem. 248, 393-402

Traub, W. \& Piez, K. A. (1971) Advan. Protein Chem. 25, 243-352

Volpin, D. \& Veis, A. (1971) Biochem. Biophys. Res. Commun. 44, 804-812

Vuust, J., Lane, J. M., Fietzek, P., Miller, E. J. \& Piez, K. A. (1970) Biochem. Biophys. Res. Commun. 38, 703-708

Williams, J. G. \& Gratzer, W. B. (1971) J. Chromatogr. 57, 121-125 